\title{
The Transition of Traditional Chinese Aesthetics by the Taoism and Neo-Confucianism in Tang and Northern Song Dynasties
}

\author{
Jing Tang ${ }^{1, *}$ \\ ${ }^{1}$ PhD, 50.06.01 Art Criticism, Russian State Specialized Academy of Arts (RGSAI), Moscow, Russia \\ *Corresponding author. Email: 22061296@qq.com
}

\begin{abstract}
The artistic characteristics of traditional Chinese culture are unique in the world and embody oriental aesthetic thoughts and Chinese philosophy. Taoism, Buddhism and Neo-Confucianism are spiritual houses that shape and nurture artistic characteristics.
\end{abstract}

Keywords: Aesthetics, Traditional Chinese culture, Taoism, Neo-Confucianism, Philosophy, Tang Dynasty, Northern Song Dynasty.

\section{INTRODUCTION}

As the opinion of Hegel, "the Philosophy of the Chinese appears to proceed from the same fundamental ideas as that of Pythagoras. The fundamental principle recognized is Reason - Tao; that essence lying at the basis of the whole, which effects everything. To become acquainted with its forms is regarded among the Chinese also as the highest science" $[1]^{155}$. Taoism is one of the oldest Chinese philosophies inherent to the Chinese nation. It was born in the deepest mind of Chinese, and soon became the foundation of Chinese culture. In the Spring and Autumn period, the infancy of world philosophies. It has influenced many fields of Chinese traditional culture and is one of the main pillars of the traditional culture of the Chinese nation. In his long-term development, he has studied politics, economy, philosophy, literature, art, music, painting, architecture, chemistry, medicine, pharmacy, health, and ethics, social customs, and nationalities in Chinese society. Relations, national psychology, national character and the formation and development of national cohesion have had a profound impact. Some of their influences have still not been neglected in the Chinese lifestyle and cultural composition.

ORCID: 0000-0002-1983-4342

\section{THE TAOISM}

Tao (道; dào) literally means "way", but can also be interpreted as road, channel, path, doctrine, or line. In Taoism, it is "the One, which is natural, spontaneous, eternal, nameless, and indescribable. It is at once the beginning of all things and the way in which all things pursue their course." It has variously been denoted as the "flow of the universe", a "conceptually necessary ontological ground", or a demonstration of nature. The Tao also is something that individuals can find immanent in themselves. Taoism differs from Confucianism by not emphasizing rigid rituals and social order but is similar in the sense that it is a teaching about the various disciplines for achieving "perfection" by becoming one with the unplanned rhythms of the universe called "the way" or "Tao" [2] ${ }^{164}$. Taoist ethics vary depending on the particular school, but in general tend to emphasize "Wuwei" (action without intention), "naturalness", simplicity, spontaneity, and the Three Treasures: "compassion", "frugality", and "humility".

In the IV century BC, early Taoism drew its cosmological notions from the "School of Yinyang (阴阳)” (Naturalists), and was deeply influenced by one of the oldest texts of Chinese culture, the "I Ching (易经)", which expounds a philosophical system about how to keep human behaviour in accordance with the alternating cycles of nature. 
The “Tao Te Ching (道德经)", a compact book containing teachings attributed to the sage "Laozi (老子)" in VI century $\mathrm{BC}$, is widely considered the keystone work of the Taoist tradition, together with the later writings of "Zhuangzi (庄子)". The basic idea of "Tao Te Ching" regards "Tao" as the root of everything in the world of time and space. It has both the meaning of the universe and the meaning of the law. Its boundaries are ambiguous, "the mysterious of mysterious". Different person can make different interpretations of it, and the different person has the unique "Tao". In "Zhuangzi", the "Tao" is interpreted as born in an original state, the mother of universe, called "Tai chi (太极)”. It very closed to the Big Bang theory.

Therefore, Taoism doesn't advocate the supremacy, the creator of all things, but the pursuit of "Tao", the way to combine with the universe as the highest aims. In Taoism, the "Tao" is the truth of the universe, the truth behind things, and the "Tao" can be understood, recognized, and interpreted by human beings. Universe is selfless, humane, and affectionate; any Taoist when he/she gains the same knowledge as the universe, which can be interpreted as "god" in other religions. That's why people feel the call of Tao on the Jun porcelain, when they found the shining blue colour in the white glaze. It is a symbol to identify they found the "Tao".

After Qin Dynasty, some fellows abandoning the original intention of Taoism, and used the philosophical thoughts of Taoism to become a religious system, “Tianshidao (天师道)”. It was founded in Sichuan by Zhang Daolin in II century. His offspring became a caesaropapism leader, reached an agreement with government in 215 to allow him to preach in Sichuan and its northern China. Therefore, the priesthood of the priest who played a leading role in the birthplace of Sichuan was beginning to support by the royal family.

\section{THE BUDDHISM AND TAOISM IN TANG DYNASTY}

In Tang Dynasty, Buddhism began to spread widely in China. It brought the Buddhist scriptures of reform, which included both the missionary content of devout faith and the exquisite Buddhist philosophy. At the same time, Buddhism also brought about an institutionalized force that China had never had before: abstinence monks gave up all secular life and dedicated their religion to their religion, advocating the value of supporting religion, this concept made the temple quickly gain a large amount of donated wealth, which created conditions for the monks to clean up their lives. Compared with Buddhism, the existence of Taoism is much easier. Taoism can develop well without church, and Buddhism is always imprisoned by its wealth. Meantime, the ancestors of the royal family of the Tang Dynasty were nobles without pure Han Chinese, and their status was relatively low in the Han Chinese society in northern China. Through the support of Taoism, high-profile claims that he is a descendant of the ancient Han sage, this is a very necessary way to improve the reputation of the royal family $[3]^{3}$. Also, the emperor even order Buddhist master Xuan Zang (玄桀) to translated the "Tao Te Ching" into Sanskrit to spread in India. Unlike the former dynasty, the government of Tang dynasty prefers to deal directly with religious leaders to replace the scattered local religious supervision. Therefore, after the first mastery philosophical debate of the Tang Dynasty between Confucianism, Taoism and Buddhism held in 624, emperor ranked Taoism in front of Confucianism, and Buddhism ranked last, even Confucianism philosopher won this debate. This debate opened the contradiction between the three major philosophies and intensified in the next few centuries, eventually causing irreparable results $[4]^{4945}$. This short-term conflict stopped at a religious localization campaign by eliminate Buddhism in 845, the success of Taoism also influenced the Chinese culture of this period.

On the other hand, Taoism also affects the Chinese aesthetic concept. For example, People in the Tang Dynasty love jade. Everything is not gorgeous, but it is cleaning as ice. It is further extended to people's temperament, such as clean, unstained, and inaction. Because of the Taoist thought and artistic thought have a natural resonance. Art is different from philosophy and religion in that art expresses the noblest things in the form of personal understanding and sensibility. This expression is closer to nature, closer to our feelings and emotions. As for what kind of perceptual forms to adopt and how to use them, it depends on the aesthetic psychology and aesthetic consciousness of the nation. The essence of art is the freedom of the theme spirit, the perfect unity of truth, goodness, and beauty. This is completely consistent with the basic aesthetic thought and the concept of freedom of Taoist philosophy. The Taoist view of the world and the concept of life, not only highlights the theme of spirituality, but also closer to the essence of art. The highest state of this spiritual activity is the integration of the soul and 
the endless nature and the universe, truly reaching the realm of the "Tao". Taoism gives nature a certain political significance and aesthetic transcendence, examines nature from a human perspective, and discovers the spiritual connotation of nature. This is not about treating nature as a cognitive object, but about the goal of treating nature as the highest spiritual quality.

As Laozi's thought "Tao that can be described is not universal and eternal Tao, Name that can be named is not universal and eternal Nam" [5] ${ }^{1}$. "Tao" is a highly abstract and individualized aesthetic concept, completely different from the figurative thinking of other civilizations. The Tang Dynasty was a very international and inclusive dynasty, from Rome to Japan, different ethnic groups and cultures are blended together. Although Chinese culture has absorbed a lot of foreign cultures in the process of historical development, Taoist ideological theory with complete system is the core view of China's cultural development for thousands of years. Therefore, Taoism believes that the concrete manifestation of the "Tao" as the root of all things lies in the virtual and empty. Virtual, can be made you inaction, but in action; Empty, in order to seek knowledge and enlightenment. Only nature can be quiet, and there is keeping quiet in the heart, whether the appearance, process, or result. This simplicity and practical thought are the highest level of beauty and a national characteristic that highlights the Chinese spirit.

\section{THE NEO-CONFUCIANISM IN NORTHERN SONG DYNASTIES}

The history of China arrived in the Northern Song Dynasty. Due to the improvement of the imperial examination system and the civil service system, the aristocratic society in the Tang Dynasty became a civilian society. Before the Northern Song Dynasty, each unified dynasty was usually a scene of prosperity, such as the Han Dynasty and the Tang Dynasty. However, the Northern Song Dynasty didn't have such a prosperous scene. In the 30 years since the estimation of the Northern Song Dynasty, large-scale peasant uprisings have repeatedly erupted. Therefore, the Northern Song Dynasty learned the lessons of the turmoil between the central government and the powerful local warlords in Tang Dynasty, strengthened the centralized system, especially strengthened the control of the military power, and made the civil servant group represented by Confucianism gain unprecedented political strength. And the
Confucianism has always been neutral and has been in control of civil servants and academic systems for the past thousand years. As we know, even the so-called Han Chinese is historically a fusion of various nationalities. For the pluralistic Chinese nation, a cultural consensus is needed as a spiritual bond to bring together all members. Such cultural consensus must have a wide acceptability. Among the three cultural resources of Confucianism, Buddhism and Tianshidao, Buddhism and Tianshidao belong to the form of religious culture, which is only acceptable to same religious believers, but not acceptable to heresies. Most Chinese are not religious. Therefore, Buddhism and Tianshidao cannot play the role of cultural consensus in China. Among the three cultural resources, only Confucianism has a wide acceptability because it is the only non-religious cultural form. On the other hand, cultural consensus is a mental phenomenon. However, Confucianism in the form of Confucian classics is mainly a political philosophy, not a philosophy of life. Such Confucianism has obvious advantages in political life, but not in mental life. It can play the role of governing the country with Confucianism, but it is difficult to receive the effect of governing the mind and body of people. Therefore, in the field of mental life, Confucian classics cannot compete with Buddhism and Tianshidao. If this situation is not changed, Confucianism will not become the cultural consensus of the whole nation. Based on political philosophy, how to talk about the philosophy of life from Confucianism, so that it has the function of governing the country, the body and the mind of people, and provides the necessary cultural consensus for the whole nation? This is a major issue that history has put forward to the NeoConfucianism. In the absence of fundamental changes in social form and political system, it is impossible for Neo-Confucianism to make any theoretical innovation in the field of political philosophy. It is their possible choice to expand the development space of Confucianism to the field of philosophy of life.

As we known, Taoism thoughts were deeply influenced into the deeply mind and spirit of Chinese thousand years, even influenced the philosophy of Buddhism. Before the advent of NeoConfucianism, the philosophy of Chinese Buddhist was not exactly the same as Indian Buddhism but returned to the idea of the unity of heaven and man in China. In Buddhism, the boundaries between present life and afterlife have become blurred. Their value orientation is not an Indian-style 
concern, but a Chinese-style concern. Although Tianshidao retains the form of religious philosophy, it is increasingly returning to the original Taoist philosophy of life. This change of Buddhism and Tianshidao provides a suitable context for the emergence of Neo-Confucianism. In this context, the Neo-Confucianist philosophers draw on the philosophical and theoretical thoughts of Buddhism and Taoism, and skilfully describe Confucianism from the argumentation of a political system as the way to settle the mental life.

Another reason why Neo-Confucianism originated in Northern Song Dynasty is that the academic environment of Northern Song Dynasty is relatively loose. After the founding of the Northern Song Dynasty, the emperor controlled the warlords very strictly, deprived them of their military power, and was more polite to the literati. He established the rule of never execute any civil servant or minister, which was the basicpolicy. In the Northern Song Dynasty, scholars had certain freedom to lecture and write books. They were allowed to set up academies. No a scholar was killed because of improper speech. Among the scholars, political differences may lead to disputes, but as long as the opponent is removed from office, he will give up and not punish him. The education in Northern Song Dynasty was more developed and many academies were set up, which provided a good atmosphere for the development of NeoConfucianism.

\section{THE TRANSITION OF TRADITIONAL CHINESE AESTHETICS}

In this stage, the introduction of new ideas and philosophies completely changed the Confucianist ideology in the past, making Neo-Confucianism became a mixture thought of Confucianism and Taoism. It pays attention to the rituals and systems of Confucianism and seeks the mental realm of Taoism. The Northern Song Dynasty philosopher Zhou Dunyi (周敦濒) is seen as the first true "pioneer" of neo-Confucianism, using Taoist metaphysics as a framework for his ethical philosophy. After him, dozens of different theoretical schools were born. At the same time that the enthusiasm for Neo-Confucianism is unprecedentedly high, the intense internal struggle of Neo-Confucianism has followed. As result of this, a philosophical vessel that can be displayed in reality has emerged. At the beginning, this vessel was designed to ingratiate the emperor, so that his school can be more intuitively projected into politics. Through the five major royal porcelain factories, all kinds of exquisite porcelains were manufactured in batches for office supplies, dedication to the gods, and daily necessities. Later on, the civil servants of Neo-Confucianism joined in the trend and further promoted it among the normal people, then making folk culture sublimation. Finally, a kind of national character is formed, and the new trend of thought of national character is formed and shaping becomes the basic element of contemporary Chinese culture.

During the Neo-Confucianist national policy and trend, has made the minds of Northern Song Dynasty introverted, and the culture of Northern Song Dynasty has become gentle, charming, delicate and exquisite. Its artistic characteristics have also turned to pay attention to the charm and elegance. Song porcelain is the perfect embodiment of this aesthetic thought. Take the Meiping as an example, the original function is the wine container, but it was designed as a blooming girl. Although the Meiping is dignified and beautiful, it is not open-minded and broad-minded, but rather flexible and gentle. In contrast, the Tang Dynasty used the largest arc to express the full effect, which is the performance of the Tang people who are extravagant and pursue the external affairs. In the Northern Song Dynasty, the pursuit of introverted and quiet styling is the embodiment of Taoist's return to the truth and the idea of "to be imaginary, to keep quiet". Through those Taoist imagination of vessels, the Neo-Confucianism got rid of the spirit of the physical servitude, so that the soul can be liberated and purified, reaching the realm of the integration of man and the universe, that is, the realm of the "Tao". In the Neo-Confucianist sense, the mutual exclusion of mentality and physiology has completely disappeared, and the two become one and the same, and they become the pursuit of vitality. So those philosophical vessels showed a tendency to shrink the size of the device as much as possible. For the size and space of the model, the Neo-Confucianism seems to be pursuing a kind of control within the square inch.

Also, the "Tao" is the original appearance of heaven. As Laozi said "For I am abstracted from the world, the world from nature, nature from the way, and the way from what is beneath abstraction" $[5]^{25}$. The nature is the state of own origin, "Tao" is the state of heaven origin, just as the so-called "Heaven changeth not; likewise, the Tao changeth not" [6] ${ }^{1}$. Taoist aesthetics was further elucidated in Northern Song Dynasty. The "Tao" is natural, Neo- 
Confucianism praise of Taoism led to the worship of natural beauty, which was regarded as the highest aesthetic realm. The pursuit of natural beauty, the removal of red tape patterns, the disdainful hypocrisy of carving, the simple natural beauty has become a model of beauty, reaching a state of natural perfection and seamless. Meanwhile, the aesthetic of "Tao" is also reflected in the appreciation of incomplete imperfections because incompleteness is also a part of nature. The people in Northern Song Dynasty could understand this kind of deformity and transform it into beauty. Under the influence of Taoism, the people in Northern Song Dynasty advocated natural reality, despised artificial traces, and pursued natural simplicity. The imperfection formed under the action of natural force is exactly the refinement and expression of the natural thought of Taoism.

\section{CONCLUSION}

Hence, we passable understand how important the philosophical vessels are to the concretization of Neo-Confucianism. It is bearing the thoughts and expectations beyond imaginations, representing the Naturalist thoughts of Taoism and the spirit of the Tang and Northern Song Dynasty. The essence of Chinese Aesthetics is to embody strong traditional Chinese culture, deep national characteristics, and humanistic spirit. For an artist, the most practical thing is to go deep into life, create nature, allow one's artistic creation to continue to sublimate, improve self-cultivation, and gradually form a set of own aesthetic imagery and formal language, only through ancient Chinese Confucianism, Taoism, and Buddhist culture by drawing nourishment from the mind can we create a more glorious new era of Chinese Aesthetics.

\section{AUTHORS' CONTRIBUTIONS}

This paper is independently completed by Jing Tang.

\section{REFERENCES}

[1] Hegel, G.W.F. Lectures on the Philosophy of History / Georg Wilhelm Friedrich Hegel, Aalten: WordBridge Publishing, 2013. - 442 p.

[2] Pollard, E.; Rosenberg, C.; Tignor, R. A History of the World - From the Beginnings of Humankind to the Present / Elizabeth Pollard; Clifford Rosenberg; Robert Tignor, - New
York: W. W. Norton \& Company; Third edition, 2011. - 992 p.

[3] Barrett, T.H. Taoism under the Tang / Timothy Hugh Barrett, - Boston: Cheng \&Tsui Co, 1996, - 110 p.

[4] Liu, X. Old Book of Tang / Chief minister Liu $\mathrm{Xu}$, - Prague: Yiya Press, Reprint edition, 2018. -6718 p.

[5] Laozi, Tao Te Ching / Laozi, - Beijing: Zhonghua Book Co, 2011. - 299 p.

[6] Ban, G. Book of Han / Ban Gu, - Prague: Yiya Press, Reprint edition, 2018. - 972 p. 